\title{
BRPKM
}

\author{
Buletin Riset Psikologi dan Kesehatan Mental \\ http://e-journal.unair.ac.id/index.php/BRPKM \\ e-ISSN: 2776-1851
}

ARTIKEL PENELITIAN

\section{Gambaran Kecerdasan Emosional Remaja yang Diasuh Ayah Tunggal}

\author{
AMITHYA NAFISAH \& IKA YUNIAR CAHYANTI* \\ Fakultas Psikologi Universitas Airlangga
}

\begin{abstract}
ABSTRAK
Penelitian ini bertujuan mengetahui gambaran kecerdasan emosional remaja yang diasuh ayah tunggal dengan perspektif teoritis kecerdasan emosional milik Goleman dengan 5 aspek yaitu mengenali emosi diri, mengendalikan emosi, memotivasi diri, memahami emosi orang lain, dan membina hubungan. Metode penelitian ini adalah kualitatif dengan pendekatan studi kasus intrinsik yang melibatkan dua orang partisipan yang terdiri dari dua remaja perempuan berusia 15-18 tahun yang diasuh oleh ayah tunggal. Teknik pengumpulan data yang digunakan adalah wawancara semiterstruktur. Teknik analisis data yang digunakan adalah analisis tematik dengan pendekatan theory driven. Hasil menunjukkan remaja yang diasuh ayah tunggal mampu mengenali emosi, penyebab dan pengaruhnya pada tindakan, mampu mengendalikan emosinya dengan menguatkan iman kepada Tuhan. Aspek memotivasi diri bersumber dari internal dan eksternal. Mampu memahami emosi orang lain dan suka membantu sesama. Remaja yang diasuh ayah tunggal menyadari pentingnya membina hubungan dan mampu hidup selaras dengan kelompok.
\end{abstract}

Kata kunci: ayah tunggal, kecerdasan emosional, remaja

\section{ABSTRACT}

This study aims to describe the emotional intelligence of adolescents who are cared by a single father with theoretical perspective of Goleman's emotional intelligence with 5 aspects, namely recognizing one's emotions, controlling emotions, motivating oneself, understanding other people's emotions, and building relationships. This research method is qualitative with intrinsic case study approach, involving two participants consisting of two teenage girls aged 15-18 years who are raised by single father. The data collection technique used was semi-structured interviews. The data analysis technique used is thematic analysis with theory driven approach. The results showed that the participants were able to recognize emotions, their causes and effects on their actions, were able to control their emotions by strengthening faith in God. Their self-motivation come from internal and external. Able to have an empathy to others. They also can recognize the importance of building relationships and being able to live in a group.

Keywords: adolescents, emotional intelligence, single father

Buletin Penelitian Psikologi dan Kesehatan Mental (BRPKM), 2021, Vol. 1(1), 768-777

*Alamat korespondensi: Fakultas Psikologi Universitas Airlangga, Kampus B Universitas Airlangga Jalan Airlangga 4-6 Surabaya 60286. Surel: ika.yuniar@psikologi.unair.ac.id 
sehingga penggunaan, distribusi, reproduksi dalam media apapun atas artikel ini tidak dibatasi, selama sumber aslinya disitir dengan baik.

\section{PE N D A H U L U A N}

Remaja adalah sebuah tahap perkembangan transisi dari masa kanak-kanak menuju dewasa. Dalam proses perkembangan tersebut mencakup beberapa perubahan, yang meliputi perubahan biologis, kognitif, dan sosio-emosional. Remaja merupakan fase perkembangan yang identic dengan fase peralihan dan fase dimana individu mulai mencari identitas diri (Erickson, 1995). Tugas perkembangan untuk mencari identitas diri membuat fase remaja menjadi rawan dengan adanya pengaruh dari lingkungannya, rawan konflik, dan mengalami ketegangan emosi yang tinggi (Nashukah \& Darmawanti, 2013). Hal tersebut membuat kemampuan mengelola emosi sangat diperlukan untuk fase remaja.

Emosi menurut Goleman (2009) adalah suatu perasaan dan pikiran khas, suatu keadaan biologis dan psikologis dan serangkaian dorongan untuk bertindak. Emosi merupakan satu aspek penting dalam kehidupan manusia karena emosi merupakan motivator perilaku dan berpengaruh pada perilaku intensional manusia. Dalam mengelola emosinya, seorang individu memiliki suatu kemampuan yang disebut dengan kecerdasan emosional. Goleman (2009) mengemukakan bahwa kecerdasan emosional adalah kemampuan seseorang mengatur kehidupan emosinya dengan intelegensi, menjaga keselarasan emosi dan pengungkapannya melalui keterampilan kesadaran diri, pengendalian dii, motivasi diri, empati dan keterampilan sosial. Kecerdasan emosional sangat dipengaruhi oleh lingkungan, tidak bersifat menetap, dapat berubah-ubah setiap saat (Thaib, 2013).

Kecerdasan emosional sangat dipengaruhi oleh faktor lingkungan terutama faktor keluarga. Keluarga sebagai lingkup terkecil akan senantiasa berinteraksi secara langsung dan mempengaruhi beberapa aspek dalam diri individu. Keutuhan orang tua dalam suatu keluarga sangat dibutuhkan dalam membentuk kepribadian dan mengembangkan diri seorang (Sholikhah, 2016). Namun keadaan tertentu membuat tidak semua keluarga dapat mempertahankan keutuhannya. Ketidautuhan keluarga ditandai dengan ketiadaan peran ayah atau ibu dalam keluarga. Hal ini memaksa anak hidup dengan kondisi diasuh oleh orang tua tunggal. Orang tua tunggal dalam pengasuhan biasanya lebih merasa tertekan daripada orang tua utuh (Maripadang, 2017). Orang tua tunggal memiliki beberapa hambatan yang kerap dihadapi dalam mengasuh anaknya. Terlebih pada ayah tunggal, karena pada umumnya pengasuhan anak seolah-olah hanya peran ibu saja.

Ayah tunggal menjalankan sendiri peran merawat, mengasuh, membimbing hingga mendisiplinkan anak (Lestari \& Amaliana, 2020). Dalam mengasuh anaknya, ayah tunggal menggunakan pola asuh demokratis yang memberikan kebebasan pada anak untuk memilih dan melakukan tindakan. Pola asuh demokratis yang diiringi dengan sikap hangat ayah akan membuat anak memiliki sifat kreatif, pandai berinteraksi, memiliki emosional yang baik dan berorientasi pada prestasi (Utami, 2020). Sari dkk., (2021) menjelaskan adanya hubungan positif antara keterlibatan ayah dalam pengasuhan terhadap tingkat kecerdasan emosional remaja. Hubungan dekat dengan ayah membuat remaja mempersepsikan ayah secara positif, sehingga mampu menjadikan ayah sebagai model dalam bersifat dan berperilaku. Di sisi lain Anggraeni (2018) mendapatkan hasil penelitian bahwa kurangnya kedekatan antara ayah tunggal dan anak remajanya akan berpengaruh pada kematangan emosi remaja. Remaja yang kurang dalam hal kedekatan dengan ayah tunggal akan memiliki perilaku yang lebih suka menyendiri, memendam permasalahan dirinya, kurang peduli dengan lingkungan sekitar, 
cemas dengan lingkungan baru, serta kurang mampu berinteraksi dengan teman-temannya.

Penulis juga melakukan wawancara untuk mengkaji fakta di lingkungan terkait kecerdasan emosional remaja yang diasuh ayah tunggal. Hasil wawancara singkat tersebut memberikan pengetahuan bahwa terdapat pengaruh dari interaksi remaja dengan ayah tunggal terhadap kecerdasan emosional. Remaja yang memiliki kedekatan dengan ayah tunggal mampu mengelola emosinya dengan baik dan memiliki keterampilan sosial yang bagus. Sedangkan remaja yang kurang mendapat perhatian ayah tunggal menunjukkan perilaku yang lebih nyaman dengan dunia pertemanannya. Jika remaja hanya nyaman dengan pertemanan, ini akan membuat mereka mudah untuk terpengaruh hal buruk.

Penelitian sebelumnya dan studi pendahuluan yang telah dilakukan tersebut mendasari keingintahuan peneliti dalam menggali gambaran kecerdasan emosional remaja yang diasuh ayah tunggal serta penjelasan mengenai keterlibatan ayah tunggal dalam membentuk kecerdasan emosional remaja.

\section{Desain Penelitian}

\section{E T O D E}

Penelitian ini menggunakan metode kualitatif dengan pendekatan studi kasus intrinsik. Pendekatan studi kasus intrinsik dipilih untuk memahami secara lebih baik kasus tertentu, atau dengan kata lain peneliti ingin mengetahui secaa intrinsik suatu fenomena, keteraturan, dan kekhususan kasus secara utuh, bukan untuk alas an eksternal lainnya (Salim, 2006).

\section{Partisipan}

Penelitian ini menggunakan teknik purposif untuk menentukan partisipan, dimana partisipan dipilih menurut kriteria tertentu. Adapun kriteria partisipan yang digunakan dalam penelitian ini adalah remaja yang berusia 15-18 tahun yang tinggal bersama ayah tunggal. Proses diawali dengan penjelasan langkah penelitian kepada partisipan, kemudian disertai dengan penandatanganan informed consent. Kedua partisipan adalah remaja yang diasuh ayah tunggal karena ibu kandungnya telah meninggal. Partisipan pertama memiliki kedekatan emosional yang baik dengan ayahnya, sedangkan partisipan kedua kurang memiliki kedekatan emosional yang baik dengan ayahnya bahkan cenderung semakin menjauh semenjak ibunya meninggal dunia.

\section{Teknik Pengumpulan Data}

Data dikumpulkan dengan wawancara semi terstruktur dengan pedoman umum. Pedoman umum dikembangkan dari tema yang telah ditentukan sebelumnya yang secara garis besar berkaitan dengan aspek-aspek kecerdasan emosional partisipan.

\section{Analisis Data}

Penelitian ini menggunakan metode analisis tematik. Analisis tematik merupakan proses mengkode informasi yang dapat menghasilkan daftar tema, model tema atau indikator yang kompleks. Dalam menyusun kode tematik penelitian ini menggunakan tipe theory driven, yaitu membuat kode yang dimulai secara konsisten dari suatu teori untuk mengembangkan kode tematik. Tahapan koding dengan Theory Driven menurut Fereday \& Muir-Cochran (2006) adalah sebagai berikut: (1) Mengembangkan manual kode dimana kode disusun, diberi label, definisi, serta deskripsi; (2) Menguji reliabilitas kode dimana pada tahap ini kode diterapkan sesuai dengan tema kasar; (3) Meringkas data 
dan mengidentifikasi tema, proses ini adalah proses parafrase dan meringkas data yang diperoleh; (4) Mengaplikasikan kode dan koding tambahan; (5) Menghubungkan kode dan mengidentifikasi tema; (5) Menyimpulkan dan menguatkan kode bertema atau dengan kata lain menyimpulkan hasil analisis dengan teori yang ada

\section{HAS I L P E N EL I T IAN}

\section{Hasil Analisis Data Partisipan 1}

Partisipan IWL merupakan remaja yang diasuh ayah tunggal. Seorang perempuan berusia 16 tahun dan duduk dibangku kelas 10 SMK. Sehari-hari ia tinggal bersama ayah dan kakak laki-lakinya. Ibunya meninggal dua tahun yang lalu. Partisipan IWL memiliki kedekatan yang cukup baik dengan ayahnya. Ia merasa ayahnya sudah seperti teman sendiri sehingga ia nyaman bercerita mengenai permasalahan sehari-hari dengan ayahnya. Ayahnya mampu mengisi peran orang tua dengan baik, mampu mengerjakan pekerjaan rumah seperti memasak dan membersihkan rumah dengan baik. Dalam mengasuh, ayah partisipan cukup tegas dalam mendisiplinkan partisipan. Namun juga senantiasa memahami, menemani putrinya ketika merasakan emosi negatif, dan menasihati dalam mengendalikan emosinya.

Dalam mengenal emosi diri, partisipan IWL kurang mampu menjelaskan keadaan emosinya dengan spontan. Emosi yang sering dirasakan adalah sedih dan tertekan. Partisipan mampu menjelaskan sebab emosi itu muncul, seperti kesedihan yang disebabkan karena rindu kepada ibunya dan perasaan tertekan yang dipicu permasalahan ekonomi keluarganya. Partisipan juga mampu memahami pengaruh emosi tersebut terhadap tindakan. Tindakan yang biasa ia lakukan ketika merasakan emosi negative adalah menangis hingga lelah, menyendiri, berkurangnya nafsu makan, dan hilangnya konsentrasi. Ayah partisipan cukup terlibat dalam proses mengenal emosi yaitu menemani, aktif bertanya kepada partisipan ketika ia sedang merasakan emosi negatif. Partisipan nyaman bercerita dan menunjukkan luapan emosi kepada ayahnya

Aspek memotivasi diri partisipan IWL cukup baik karena ia menunjukkan sikap yang optimis dan percaya diri dengan kemampuan dirinya. Sumber kekuatannya adalah dirinya sendiri. Ia juga mampu fokus dalam mengerjakan tugas. Dalam memotivasi diri untuk menghadapi hal negatif, partisipan melakukan internalisasi kepada diri sendiri bahwa keadaan buruk tidak akan berlangsung selamanya. Ayah partisipan selalu mendukung putrinya, memberikan kepercayaan penuh terhadap keinginan anaknya. Ayahnya selalu memotivasi putrinya untuk melanjutkan sekolah serta memberikan nasihat mengenai pencapaian cita-cita.

Partisipan mampu mengendalikan emosi negatif dengan cukup baik. Meskipun ia bisa bertindak agresif dan menunjukkan luapan emosinya dengan ekspresif. Namun ia mampu mengendalikannya yaitu dengan menulis buku harian, berdzikir dan mengingat Tuhan. Ketika merasakan emosi negatif, partisipan IWL tidak mudah menceritakan masalah terdalamnya dengan orang lain karena ia lebih nyaman merasakannya sendiri. Ayah partisipan memberikan contoh dalam mengendalikan emosi yaitu diam untuk menenangkan diri. Hal tersebut membuat partisipan IWL meniru sikap ayahnya tersebut dalam mengendalikan emosi.

Kemampuan mengenal emosi orang lain atau berempati dimiliki oleh partisipan. Hal yang ditunjukkan oleh partisipan adalah suka mendengarkan dan memberikan solusi kepada teman-temannya yang 
sedang ada masalah. Ia mampu berinisiatif membantu orang lain tanpa diminta. Dalam mendengarkan pendapat orang lain, partisipan IWL lebih mudah mendengarkan orang yang memiliki kedekatan emosional dengan dirinya. Kemampuan partisipan dalam mengenal emosi orang lain tidak lepas dari interaksinya dengan sang ayah. Partisipan selalu mendengarkan nasihat ayahny, mengamati dan meniru cara ayahnya memperlakukan orang di sekitarnya yang membutuhkan.

Dalam membina hubungan, partisipan mampu memahami pentingnya membina hubungan dan mampu hidup berkelompok namun ia kurang suka bergaul dengan orang baru. Partisipan tidak terlalu mengutamakan pertemanan karena ia selalu mengutamakan dirinya. Di antara banyak teman yang ia miliki, hanya ada beberapa teman yang begitu dekat dengannya. Partisipan juga mampu menyelesaikan konflik dengan baik. Aspek membina hubungan ini juga tidak lepas dari pengaruh ayah partisipan yang memberikan contoh kepada anaknya bagaimana cara berteman dan membina hubungan dengan orang di sekitarnya.

\section{Hasil Analisis Data Partisipan 2}

Partisipan NA merupakan remaja berjenis kelamin perempuan yang berusia 18 tahun dan duduk di bangku kelas 12 SMA. NA sehari-hari tinggal dengan ayahnya. Ia memiliki kakak laki-laki yang bekerja di luar kota. Meskipun tinggal berdua dengan ayahnya, Ibu kandung partisipan meninggal dunia satu tahun yang lalu karena penyakit kanker yang dideritanya sejak lama. Semenjak kepergian ibunya, ia merasa hubungan dengan ayahnya semakin menjauh. Komunikasi mereka lakukan seadanya dan jarang berdiskusi bersama. Pekerjaan rumah juga dilakukan dengan dasar kesadaran masing-masing.

NA mampu mengenal emosi diri dan menjelaskannya secara spontan. Emosi yang dominan dialami adalah kesedihan mendalam karena kehilangan ibunya. Partisipan NA kehilangan tempat berbagi cerita dan sosok yang memberi kehangatan dalam keluargnya. Ia juga mampu memahami pengaruh emosinya terhadap tindakan. Ia menjadi lebih berusaha terbuka dan toleran terhadap keadaan. Ia berusaha untuk menghargai apa yang ia punya. Menurut NA, ayahnya kurang berusaha memahami anaknya. Sehingga NA tidak bisa nyaman mengungkapkan luapan emosi terhadap ayahnya.

Dalam memotivasi diri, NA adalah seseorang yang memiliki sumber motivasi yang berasal dari luar dirinya, seperti keberadaan keluarga atau orang yang ia sayangi. Ketika ibunya meninggalkannya, ia merasa kebingungan mencari sumber motivasi diri. Ia kemudian menjadikan keluarga sebagai sumber motivasinya. Di samping itu, ia mampu berkonsentrasi pada tugas dan kewajibannya. Dalam aspek ini, ayah partisipan kurang mampu diajak berdiskusi perihal masa depan anaknya. Ayah partisipan hanya membebaskan tanpa memberikan saran dan komunikasi yang baik.

Partisipan NA mampu mengendalikan emosinya dengan baik. Yang sering ia lakukan adalah dengan menangis sendiri, menenangkan diri dengan beribadah dan mengingat Tuhan. NA tidak pernah bertindak agresif. Semenjak tinggal dengan ayah tunggal, ia menjadi lebih tenang dan sabar dalam menghadapi suatu masalah. Dalam pengendalian emosi ini, ayah partisipan tidak mampu menjadi model kecerdasan emosional bagi partisipan karena ayahnya tidak pernah menunjukkan berbagai emosi di depannya. Cara pengendalian emosi yang diterapkan partisipan dikembangkan sendiri.

Mengenal emosi orang lain mampu dimunculkan oleh partisipan. Ia juga mampu bersikap terbuka terhadap perbedaan pendapat dan mampu memikirkan sudut pandang orang lain. Sehari-hari ia bersedia meminta dan memberikan bantuan kepada temannya yang membutuhkan. Dalam pembentukan sikap empati ini, partisipan lebih merasa meniru mendiang ibunya. 
Partisipan NA mampu menyadari pentingnya membina hubungan dengan orang lain. Pertemanan merupakan hal yang penting baginya. Ia juga suka bergaul dengan orang baru, mampu hidup berkelompok serta jarang berkonflik dengan orang lain secara pribadi.

Hubungan baik yang terjalin antara partisipan dengan teman-temannya juga dipengaruhi oleh cara partisipan melihat hubungan ayahnya dengan orang di sekitarnya. Partisipan melihat hubungan ayahnya dengan orang lain terjalin cukup baik. Baik itu teman, tetangga, atau juniornya.

\section{I S K U S I}

Kecerdasan emosional merupakan kemampuan individu untuk mengenali emosi diri, mengenal emosi orang lain, mengendalikan emosi, memotivasi diri sendiri, dan membina hubungan dengan orang lain (Goleman, 2009). Mengenal emosi diri adalah kesadaran diri atau pengenalan ketika suatu emosi (perasaan) timbul. Kemampuan memantau perasaan dari waktu ke waktu merupakan dasar dari kecerdasan emosional. Kemampuan mengenal emosi diri telah dimiliki oleh kedua partisipan. Baik partisipan pertama maupun kedua mampu menjelaskan keadaan emosinya dengan baik. Keadaan emosi serta pengaruhnya terhadap tindakan dapat dijelaskan oleh kedua partisipan.

Memotivasi diri sendiri merupakan kemampuan menata emosi sebagai alat untuk mencapai tujuan (Goleman, 2009). Seseorang dengan kemampuan motivasi diri akan lebih bisa menguasai dirinya. Dalam hal ini, kedua partisipan dapat fokus terhadap tugas dalam mencapai tujuannya. Namun terdapat perbedaan antara keduanya. Partisipan pertama memiliki sumber motivasi yang berasal dari dalam dirinya, ia cenderung lebih optimis dibandingkan dengan partisipan kedua. Partisipan kedua lebih mendapatkan kekuatan dari luar dirinya yaitu keberadaan keluarga.

Mengendalikan emosi diri Goleman (2009) merupakan kemampuan untukmenghadapi luapan emosi. Pengendalian emosi bertujuan untuk menyeimbangkanemosi tidak untuk meredamnya karena setiap emosi memiliki nilai dan makna tersendiri. Kehilangan sosok yang dicintai adalah hal yang tidak menyenangkan. Oleh karenanya partisipan kemudian perlu untuk mengendalikan emosi negatif yang dialaminya. Dalam mengendalikan emosinya, ada perbedaan cara dari kedua partisipan. Partisipan pertama memiliki cenderung lebih ekspresif dalam meluapkan emosinya. Sedangkan partisipan kedua lebih suka berbagi cerita dengan orang lain namun lebih sabar dan tenang dalam menghadapi masalah. Kedua partisipan juga mengendalikan emosi dengan memperkuat ibadah dan mengingat Tuhan.

Empati atau mengenal emosi orang lain adalah kemampuan untuk mengetahui perasaan orang lain (Goleman, 2009). Orang yang berempati lebih mampu menangkap sinyal sosial tersembunyi yang mengisyaratkan sesuatu yang dibutuhkan orang lain. Kemampuan ini merupakan dasar dari kemampuan bergaul. Partisipan pertama lebih mampu mendengarkan orang yang memiliki kedekatan emosional dengannya. Sedangkan partisipan kedua lebih memahamisudut pandang orang lain yang berbeda-beda. Perbedaan pendapat adalah hal yang sangat biasa baginya. Meskipun terdapat sedikit perbedaan dalam hal memandang sudut pandang orang lain, kedua partisipan cukup baik dalam memberikan bantuan terhadap orang lain dengan tulus.

Mengendalikan emosi diri sendiri dan memahami orang lain merupakan landasan yang baik dalam menjalin hubungan dengan orang lain. Jadi, memiliki kemampuan mengendalikan diri sendiri dan mengatur empati terhadap orang lain akan mendukung keberhasilan individu dalam dunia sosial. 
Orang dengan kemampuan membina hubungan dengan orang lain akan memungkin mereka untuk membentuk hubungan, membina kedekatan, mengatasi konflik dan mampu hidup selaras dengan kelompok (Goleman, 2009). Kedua partisipan mampu memahami pentingnya membina hubungan dan mampu hidup selaras dengan kelompok. Namun partisipan pertama adalah seseorang yang lebih fokus dengan dirinya sendiri. Ia merasa kehadiran teman bukanlah hal yang penting karena ia lebih memiliki sumber kekuatan dari dirinya sendiri. Ia juga kurang mampu membangun pergaulan dengan orang baru dan hidup berkelompok. Berbeda dengan partisipan kedua yang lebih mencari kenyaman dengan teman-teman dan keluarganya. Partisipan kedua ini juga suka berorganisasi dan mencari teman baru.

Penelitian Nurita (2012) yang menerangkan bahwa salah satu yang menjadi faktor kecerdasan emosional anak adalah faktor lingkungan dimana keluarga adalah lingkungan terkecil yang menentukan perkembangan individu. Keluarga merupakan tempat pertama untuk mempelajari emosi, dalam keluarga, kita belajar bagaimana merasakan perasaan kita sendiri dan bagaimana orang lain menanggapi perasaan kita, bagaimana berfikir tentang perasaan ini dan pilihan-pilihan apa yang kita miliki untuk bereaksi, serta bagaimana membaca dan mengungkap harapan dan rasa takut. Pembelajaran emosi bukan hanya melalui hal-hal yang diucapkan dan dilakukan oleh orang tua secara langsung pada anak-anaknya, melainkan juga melalui contoh-contoh yang mereka berikan ketika menghadapi perasaan yang muncul.

Konteks ayah tunggal sendiri merupakan konteks yang menarik untuk diteliti karena merupakan salah satu bentuk struktur keluarga yang tidak utuh dan tentunya memiliki beberapa tantangan dalam pengasuhan. Ayah tunggal mengalami perubahan peran dalam menjalankan pengasuhan anak. Bila semula ayah berperan sebagai penanggungjawab utama dalam mencari nafkah, namun keadaan membuat ayah harus merangkap tugas mencari nafkah dan mengasuh anak. Ayah menjalankan sendiri peran merawat dan mengasuh anak, mulai dari perawatan diri hingga pembimbingan anak dan mendisplinkan anak (Lestari \& Amaliana, 2020). Terkait hal ini, yang dialami oleh kedua partisipan cukup mewakili pernyataan tersebut. Partisipan pertama memiliki ayah yang berkomitmen untuk tidak menikah lagi, selain itu juga ayah partisipan mampu melaksanakan peran ibu dengan cukup baik dan tanpa mengeluh. Ayah partisipan pertama juga menjalankan tugas mendidik dan mendisiplinkan anaknya. Sedangkan keadaan partisipan kedua terdapat sedikit perbedaan karena komunikasi antara anak dan ayah tunggal sangat minim. Pekerjaan rumah dilaksanakan sendiri-sendiri.

Penelitian lain yang dilakukan Utami (2020) menjelaskan bahwa dalam mengasuh anaknya, ayah tunggal menggunakan pola asuh yang memberikan kebebasan kepada anak untuk memilih dan melakukan suatu tindakan, selain itu pendekatan ayah tunggal kepada anak bersikap hangat serta tidak memaksakan kehendak kepada anak. Anak yang hidup dalam pola asuh ini memiliki sifat kreatif, berinteraksi baik dengan temannnya, emosional yang baik dan berorientasi pada prestasi. Hal ini sesuai dengan partisipan kedua yang diberikan kebebasan penuh dalam memilih keputusan. Namun kebebasan ini tidak disertai dengan sikap hangat dari sang ayah kepada anaknya, sehingga yang dirasakan oleh partisipan kedua lebih pada kebingungan dalam menentukan pilihan masa depannya.

Sari dkk., (2021) menjelaskan adanya hubungan positif antara keterlibatan ayah dalam pengasuhan terhadap tingkat kecerdasan emosional remaja. Adanya hubungan yang dekat dengan ayah membuat remaja mempersepsikan ayah secara positif, sehingga remaja cenderung menjadikan ayah sebagai 
model baik dalam bersifat dan berperilaku. Hal ini sesuai dengan penelitian ini, dimana adanya keterlibatan ayah yang dominan dalam mengasuh anaknya akan membuat remaja menjadikan model baik dalam bersifat dan berperilaku. Kontras dengan hal itu, partisipan kedua yang keterlibatan ayahnya cukup minim menjadikan partisipan kedua canggung berkomunikasi dengan ayahnya. Dalam berperilaku juga remaja yang kurang dekat dengan ayahnya lebih mengingat interaksinya dengan mendiang ibunya.

Theresiana (2018) juga meneliti mengenai pengaruh pengasuhan ayah tunggal terhadap perilaku remaja, yakni gambaran perilaku agresif remaja yang tinggal bersama ibu tunggal dan ayah tunggal. Hasil yang didapatkan yakni remaja yang tinggal dengan ayah tunggal cenderung lebih memiliki tingkat perilaku agresif yang rendah. Rendahnya tingkat agresifitas remaja yang diasuh ayah tunggal ini secara tidak langsung menjelaskan bahwa remaja yang diasuh ayah tunggal cenderung lebih mampu mengelola emosinya dengan baik. Penelitian tersebut, kurang sesuai dengan hasil penelitian ini, karena tingkat agresifitas remaja lebih berasal dari faktor internal individu bukan karena sebab interaksi dengan ayah tunggal. Perilaku itu telah muncul jauh sebelum pengasuhan ayah tunggal terjadi dalam remaja.

Penelitian lain yang dilakukan Anggraeni (2018) Kedekatan ayah tunggal dengan anaknya cukup berpengaruh terhadap perkembangan anak. Remaja yang kurang memiliki kedekatan dengan ayah tunggal memiliki perilaku yang lebih suka menyendiri, memendam permasalahan dirinya, kurang peduli dengan keadaan sekitar, cemas dengan lingkungan baru, serta kurang suka berinteraksi dengan teman-temannya. Pernyataan tersebut tidak sepenuhnya benar. Hasil penelitian ini mencoba melengkapi penelitian Anggraeni (2018) bahwa remaja yang kurang memiliki kedekatan dengan ayah tunggal memang ada yang lebih suka memendam perasaan terdalamnya namun hal itu dikarenakan remaja mencoba memahami kondisi ayah mereka. Selain itu, pada penelitian ini remaja tidak kurang peduli dengan keadaan sekitar, bahkan mereka mampu berempati dengan orang di sekitarnya, dan suka berinteraksi dengan teman-teman. Namun pertemanan lebih diperhatikan dari segi kualitas bukan kuantitas.

\section{S I M P U L A N}

Kesimpulan yang dapat diambil dari penelitian ini adalah remaja yang diasuh ayah tunggal mampu mengenal emosi dirinya beserta penyebab dan pengaruhnya terhadap tindakan. Remaja yang diasuh ayah tunggal masih diselimuti kesedihan akibat kehilangan ibunya. Dalam mengelola emosinya, remaja yang diasuh ayah tunggal memiliki cara masing-masing dalam mengendalikan emosi yang muncul. Yang menonjol dari cara mengendalikan emosinya adalah dengan beribadah dan mengingat Tuhan. Remaja yang memiliki kedekatan dengan ayah tunggal mampu mengekspresikan luapan emosinya sedangkan remaja yang kurang memiliki kedekatan dengan ayah tunggal lebih memendam dan merasakannya sendiri atau menceritakan kepada teman terdekatnya. Dalam memotivasi diri sendiri remaja yang diasuh ayah tunggal memiliki sumber motivasi yang berasal dari dalam diri maupun dari luar diri atau keluarganya. Meskipun memiliki sumber motivasi dari luar dirinya, remaja yang diasuh ayah tunggal mampu fokus terhadap tugas yang dimiliki. Keterampilan memahami emosi orang lain (empati) remaja yang diasuh ayah tunggal mampu memahami perasaan orang lain serta mampu memberikan bantuan kepada orang yang membutuhkan. Sedangkan dalam hal membina hubungan dengan orang lain, remaja yang diasuh ayah tunggal memiliki pandangan yang berbedabeda dalam memaknai pertemanan. Namun remaja yang diasuh ayah tunggal mampu hidup selaras dengan kelompok dan menyadari pentingnya membina hubungan dengan orang lain. 
Kedekatan dengan ayah mempengaruhi pembentukan kecerdasan emosional remaja. Remaja yang dekat dengan ayah tunggal mampu memiliki persepsi positif kepada ayahnya sehingga mampu meniru sifat dan perilaku ayahnya. Sedangkan remaja yang kurang memiliki kedekatan emosional dengan ayah tunggal tidak menjadikan ayahnya sebagai model kecerdasan emosionalnya.

Penelitian ini telah menggali tentang kecerdasan emosional remaja yang diasuh ayah tunggal dengan riwayat cerai meninggal. Untuk Penelitian selanjutnya disarankan untuk dapat menggunakan partisipan dengan remaja yang diasuh oleh ayah tunggal khususnya ayah tunggal akibat cerai hidup karena akan memunculkan dinamika yang berbeda. Selain itu, penelitian ini diharapkan dapat memberikan pengetahuan bagi remaja untuk membangun kecerdasan emosional dengan baik untuk mempersiapkan diri menghadapi masa dewasa, serta mampu memberikan pengetahuan bagi ayah tunggal mengenai pentingnya menjalin kedekatan emosional dengan anaknya untuk membangun kecerdasan emosional dan ketrampilan sosial yang baik untuk anaknya.

\section{U C A P A N T ERIMAKASIH}

Penulis mengucapkan terima kasih kepada seluruh pihak yang berkontribusi dalam penyusunan penelitian ini terutama kepada seluruh partisipan yang terlibat.

\section{DEKLARASI POTENSI TERJADINYAKONFLIK KEPENTINGAN}

Amithya Nafisah dan Ika Yuniar Cahyanti tidak bekerja, menjadi konsultan, memiliki saham, atau menerima dana dari perusahaan atau organisasi manapun yang mungkin akan mengambil untung dari diterbitkannya naskah ini.

\section{P US T A KA ACUAN}

Anggraeni, R. (2018). Kematangan Emosi Remaja Yang Memiliki Orang Tua Tunggal.

Erickson, E. (1995). Identity: Youth and Crisis. W. W. Norton Co.

Fereday, J., \& Muir-Cochran, E. (2006). Demonstrating Rigor Using Thematic Analysis: A Hybrid Approach of Inductive and Deductive Coding and Theme Development. International Journal of Qualitative Method, 5, 1-11.

Goleman, D. (2009). Emotional Intelligence. Kecerdasan Emosional Mengapa EI Lebih Penting Daripada IQ (Terjemahan T. Hermaya) (7th ed.). PT. Gramedia Pustaka Utama.

Lestari, S., \& Amaliana, N. (2020). Peran Ayah Sebagai Orang Tua Tunggal Dalam Pengasuhan Anak. Jurnal Sains Psikologi, 9(1).

Maripadang, S. (2017). Peran Single Parent Dalam MenjalankanFungsi Keluarg.

Nashukah, F., \& Darmawanti, I. (2013). Perbedaan Kematangan Emosi Remaja Ditinjau dari Struktur Keluarga. Jurnal Psikologi: Teori \& Terapan, 3(2). 
Nurita, M. (2012). Hubungan Antara Kecerdasan Emosional dengan Kinerja Perawat Pada Rumah Sakit Umum Pusat Fatmawati Jakarta Selatan. Jurnal Fakultas Psikologi Universitas Gunadarma.

Salim, A. (2006). Teori dan Paradigma Penelitian Sosial Buku Sumber Untuk Penelitian Kualitatif. PT. Tiara Wacana.

Sari, A. ., Rosalita, R., \& Anggraeni, Y. (2021). Hubungan Keterlibatan Ayah Dalam Pengasuhan Dengan Kecerdasan Emosi Remaja. Jurnal Cakrawala Promkes, 3(1).

Sholikhah, A. (2016). problematika dan resiliensi keluarga bercerai. UIN Sunan Kalijaga.

Thaib, E. . (2013). Hubungan Antara Prestasi Belajar dengan Kecerdasan Emosional. Jurnal Ilmiah Didaktika.

Theresiana, R. S. . (2018). Gambaran Perilaku Agresif Remaja yang Tinggal Bersama Ibu Tunggal dan Ayah Tunggal.

Utami, K. . (2020). Pola Asuh Anak Dalam Keluarga Single Paren (Ayah Tunggal). 